\title{
Pengembangan Sistem Informasi Perpustakaan Sekolah Berbasis Web
}

\author{
Savira Granita ${ }^{1}$, Siti Rohmaniyah ${ }^{2}$, Tio Goutama ${ }^{3}$, Yulianti ${ }^{4}$ \\ Teknik Informatika, Universitas Pamulang, Tangerang Selatan, Indonesia, 15417 \\ E-mail: ${ }^{1}$ saviragrnt10@gmail.com, ${ }^{2}$ neyrohma@gmail.com, ${ }^{3}$ tiogautama018@gmail.com, \\ ${ }^{4}$ yulianti@unpam.ac.id
}

Submitted Date: October $02^{\text {nd }}, 2020$

Revised Date: October $10^{\text {th }}, 2020$
Reviewed Date: October $08^{\text {th }}, 2020$

Accepted Date: October $31^{\text {st }}, 2020$

\begin{abstract}
The school library is a means for teachers and students to find information. The school library provides books or reading materials that can support the learning process. The focus of this research is to develop the information system contained in the school library. Many school libraries still collect data in the conventional way, such as handwritten using a ledger or using excel. The development of this school library system will use the website as a means to process data. The data that has been created will be entered into the data storage using the MySQL application as the database. This research planning uses the SDLC method with the waterfall model. The waterfall model is used because it is considered more efficient in developing school libraries. There are two entities that can use this website, namely library officers and members. Library officers can use the web to process data on book procurement, book borrowing transactions and viewing library reports. Meanwhile, members can fill in the guest book every time they visit the school library and also do book searches. Thus, the school library information system can facilitate the data processing. Book lending and borrowing transactions will also be more efficient and errors in data processing can be reduced.
\end{abstract}

Keyword: Library; school; information

\begin{abstract}
Abstrak
Perpustakaan sekolah merupakan sarana untuk guru dan murid mencari informasi. Perpustakaan sekolah menyediakan buku atau bacaan yang dapat menunjang proses pembelajaran. Fokus penelitian kali ini adalah untuk mengembangkan sistem informasi yang terdapat pada perpustakaan sekolah. Banyak perpustakan sekolah yang masih melakukan pendataan dengan cara konvensional seperti ditulis tangan menggunakan buku besar ataupun menggunakan excel. Pengembangan sistem perpustakaan sekolah ini akan menggunakan website sebagai sarana untuk mengolah data. Data yang sudah dibuat akan dimasukan ke dalam penyimpanan data menggunakan aplikasi MySQL sebagai basis data. Perencanaan penelitian ini menggunakan metode SDLC dengan model waterfall. Model waterfall digunakan karena dianggap lebih efisien dalam untuk pengembangan perpustakaan sekolah. Terdapat dua entitas yang dapat menggunakan website ini yaitu petugas dan anggota perpustakaan. Petugas perpustakaan dapat menggunakan web untuk mengolah data pengadaan buku, transaksi pinjam-meminjam buku dan melihat laporan perpustakaan. Sedangkan anggota dapat mengisi buku tamu setiap berkunjung ke perpustakaan sekolah dan juga melakukan pencarian buku. Dengan demikian, sistem informasi perpustakaan sekolah dapat mempermudah proses pengolahan data. Transaksi pinjam-meminjam buku juga akan lebih efisien dan kesalahan dalam pengolahan data dapat berkurang.
\end{abstract}

Keyword: Perpustakaan; sekolah; informasi 


\section{Pendahuluan}

Perpustakaan sekolah merupakan tempat bagi siswa/siswi maupun guru untuk sekedar membaca atau mencari informasi melalui buku (Adithama \& Maslim, 2019) (Anggoro \& Hidayat, 2020). Perpustakaan sekolah menyediakan buku pelajaran dan bacaan yang menyangkut dengan proses belajar. Tanpa adanya perpustakaan sekolah, maka proses belajar akan sulit mengingat banyak informasi yang bisa didapatkan di perpustakaan sekolah. Seiring berjalannya waktu, informasi yang ada semakin banyak dan berkembang pesat.

Masih banyak penerapan sistem informasi perpustakaan yang dikelola dengan cara konvensional oleh pihak sekolah seperti ditulis tangan lalu dimasukkan ke dalam buku besar atau siswa yang kesulitan mencari buku karena daftar buku harus dilihat satu persatu (Aini, Wicaksono, \& Arwani, 2019). Pengolahan data yang dilakukan dengan cara tersebut akan menyulitkan petugas perpustakaan sekolah. Selain itu, proses yang dilakukan rentan terjadi kesalahan pada saat mengelola data. Kesalahan ini dapat menyebabkan kerugian - kerugian yang seharusnya tidak pernah ada.

Pengembangan sistem informasi diharapkan dapat menjadi alternatif untuk mempermudah pengolahan data. Sistem informasi yang dikembangkan akan berbasis website dengan penggunaan basis data sebagai ruang penyimpanan data.

Sistem informasi berbasis web dapat mempermudah pengolahan data yang masih disusun secara konvensional. Dengan web maka pengolahan akan jelas, rapih dan tersusun. Sehingga akan mengurangi resiko kesalahan yang dapat menimbulkan kerugian.

Pada web ini nantinya akan dibuat proses pengolahan data yang sebelumnya dibuat dengan cara konvensional. Petugas perpustakaan akan bisa memasukkan data siswa yang meninjam buku, mengembalikan buku dan melihat denda jika anggota telat mengembalikan buku. Sedangkan anggota bisa mencari buku yang dibutuhkan dengan mudah.

\section{Metode penelitian}

\subsection{Tahap Pengembangan}

Metode penelitian ini menggunakan metode SDLC (Software Development Life Cycle) dengan model waterfall seperti yang sudah dilakukan oleh beberapa peneliti sebelumnya. SDLC atau software development life cycle (Pressman, 2015) adalah poses mengembangkan atau mengubah suatu sistem Perangkat lunak dengan menggunakan modelmodel dan metodologi yang digunakan orang untuk mengembangkan sistem perangkat lunak sebelumnya (Shalahuddin \& Sukamto, 2014).

Model waterfall adalah model klasik yang bersifat sistematis, berurutan dalam membangun software. Model ini melakukan pendekatan secara sistematis dan berurutan. Disebut dengan waterfall karena tahap demi tahap yang dilalui harus menunggu selesainya tahap sebelumnya dan berjalan berurutan (Pressman, 2015). Model waterfall memiliki beberapa tahapan, yaitu perencanaan (planning), analisis, desain, implementasi, testing dan maintenance. Berikut ini penjelasannya:

1) Planning

Melakukan perencanaan sistem yang akan dibuat. Perencanaan mencakup kelayakan lingkungan, organisasi dan ekonomi.

2) Analisis

Merupakan proses mengamati sistem, pada tahap ini akan dilakukan pengamatan terhadap kebutuhan, fungsi dan pengguna sistem.

3) Desain

Merupakan gambaran sistem yang nanti akan dibuat berdasarkan hasil analisis sistem.

4) Implementasi

Setelah dilakukan analisis dan desain sistem, tahap ini akan melakukan pengembangan terhadap sistem yang akan dibuat berupa bahasa pemrograman komputer.

5) Testing

Pada tahap ini, sistem yang sudah terbentuk akan diuji untuk mengetahui apakah sistem tersebut sudah layak digunakan. Pengujian perangkat lunak merupakan tahap yang harus dilalui untuk menjamin kualitas sistem/aplikasi yang dikembangkan (Pratala, Asyer, Prayudi, \& Saifudin, 2020). Pengujian merupakan suatu rangkaian aktivitas yang terencana dan sistematis untuk menguji atau mengevaluasi kebenaran fungsi aplikasi berdasarkan desain kasus uji (test case) yang spesifik (Yulistina, Nurmala, Supriawan, Juni, \& Saifudin, 2020).

6) Maintenance

Sistem yang sudah diuji dan layak pakai akan diterapkan dan digunakan oleh pengguna. Dalam proses ini, sistem akan selalu dipantau dan dipelihara untuk meminimalisir kerusakan sistem. 


\subsection{Tahap Planning}

Dalam penulisan dan pengumpulan data, penulis menggunakan metode penelitian kepustakaan (library research). Penelitian kepustakaan adalah pengumpulan data yang dilakukan dengan mencari jurnal atau data-data dari referensi yang terkait dengan judul.

\subsubsection{Analisa Kelayakan Teknis}

Data dalam perpustakaan sekolah umumnya masih dilakukan manual dengan menggunakan buku ataupun software seperti Microsoft excel yang masih rentan akan kesalahan (Khudri \& Oktariansyah, 2020). Alternatif untuk mengganti sistem tersebut yaitu menggunakan website. Inti dari pengembangan sistem ini adalah untuk memudahkan petugas perpustakaan dalam pengolahan data dan mengurangi kesalahan yang rawan terjadi (Putera \& Ibrahim, 2018).

Penelitian menggunakan perancangan input dengan bahasa pemrograman PHP yang akan diterapkan ke dalam pembuatan web. Untuk perancangan hasil pengolahan data akan menggunakan MySQL sebagai database.

\subsubsection{Analisa Organisasi}

Analisa ini dilakukan untuk memastikan perlakuan pegawai/karyawan mendukung atau tidak. Penulis telah memastikan bahwa di era teknologi saat ini banyak petugas perpustakaan sekolah yang mengerti dan paham dengan perkembangan teknologi. Teknologi informasi ditujukan untuk membantu pekerjaan dengan menyediakan informasi dan melakukan berbagai tugas yang berhubungan dengan pengolahan informasi (Hanum \& Saifudin, 2019). Maka, pegawai akan mudah menerima sistem tersebut Untuk membuat pengembangan sistem berjalan dengan baik, maka diperlukan beberapa tenaga ahli, yaitu:

1) $U I / U X$ Designer

Tugas desain UI adalah membuat perancangan sistem perangkat lunak berdasarkan visual dari pengguna (user) menjadi menarik atau mudah digunakan.

2) Programmer

Melakukan pengembangan sistem dengan menggunakan Bahasa pemrograman komputer.

\subsubsection{Analisa Ekonomi}

Pada analisa kelayakan ekonomi akan dipastikan apakah sistem yang dibuat akan menguntungkan atau tidak. Analisa ini juga bersangkutan pada perhitungan biaya dan manfaat (cost and benefit). Sistem yang dibangun harus mempunyai nilai secara keuangan. Dihitung dengan membandingkan antara keuntungan dan manfaat yang diperoleh.

Tujuan dari pengembangan sistem adalah membantu perpustakaan sekolah saat melakukan pengolahan data (Puspitasari, 2016). Dalam proses pengolahan data tersebut tentu ada beberapa keuntungan. Rician biaya dan keuntungan akan penulis bagikan dalam bentuk tabel di bawah ini:

Tabel 1. Rincian Biaya dan Manfaat

\begin{tabular}{|c|c|c|c|c|c|c|}
\hline $\begin{array}{c}\text { Rincian biaya dan } \\
\text { manfaat }\end{array}$ & Tahun 2020 & $\begin{array}{c}\text { Tahun } \\
\mathbf{2 0 2 1}\end{array}$ & $\begin{array}{c}\text { Tahun } \\
\mathbf{2 0 2 3}\end{array}$ & $\begin{array}{c}\text { Tahun } \\
\mathbf{2 0 2 4}\end{array}$ & $\begin{array}{c}\text { Tahun } \\
\mathbf{2 0 2 5}\end{array}$ & Total \\
\hline 1. Biaya perangkat & & & & & & \\
\hline 1) Hardware & 8.000 .000 & - & - & - & - & \\
\hline 2) Software & 5.800 .000 & - & - & - & - & \\
\hline 2. Biaya Perawatan & & & & & - & \\
\hline 1) Penerapan sistem & 600.000 & - & - & - & - & \\
\hline 2) Perawatan & - & 800.000 & 900.000 & 950.000 & 1.000 .000 & \\
\hline 3) Alat Tulis & - & 300.000 & 350.000 & 400.000 & 500.000 & \\
\hline Total Biaya & 14.400 .000 & 1.100 .000 & 1.250 .000 & 1.350 .000 & 1.500 .000 & 19.600 .000 \\
\hline PV Biaya & 13.714 .285 & 1.047 .619 & 1.190 .476 & 1.285 .714 & 1.428 .571 & \\
\hline PV Seluruh Biaya & 13.714 .285 & 14.761 .904 & 15.952 .380 & 17.238 .094 & 18.666 .665 & \\
\hline 3. Rincian Manfaat & & & & & & \\
\hline $\begin{array}{c}\text { 1) Pengurangan } \\
\text { Kesalahan }\end{array}$ & - & 3.000 .000 & 4.000 .000 & 5.000 .000 & 6.000 .000 & \\
\hline $\begin{array}{c}\text { 2) Pengurangan } \\
\text { biaya operasi }\end{array}$ & - & 1.500 .000 & 2.000 .000 & 2.500 .000 & 3.000 .000 & \\
\hline
\end{tabular}




\begin{tabular}{|l|c|c|c|c|c|c|}
\hline $\begin{array}{c}\text { 3) Peningkatan } \\
\text { Efisiensi kerja }\end{array}$ & - & 4.000 .000 & 5.000 .000 & 6.000 .000 & 7.000 .000 & \\
\hline Total Manfaat & & 8.500 .000 & 11.000 .000 & 13.500 .000 & 16.000 .000 & 49.000 .000 \\
\hline PV Manfaat & & 8.095 .238 & 10.476 .190 & 12.857 .142 & 15.238 .095 & \\
\hline PV Seluruh Manfaat & 8.095 .238 & 18.571 .428 & 31.428 .570 & 46.666 .665 & \\
\hline $\begin{array}{l}\text { Selisih biaya dan } \\
\text { manfaat }\end{array}$ & -13.174 .285 & 952.381 & 9.190 .476 & 20.761 .904 & 34.571 .428 & \\
\hline NPV & -13.832 .993 & 1.050 .000 & 10.638 .895 & 25.225 .713 & 27.093 .595 & \\
\hline Kumulatif NPV & -13.832 .993 & -12.782 .993 & -2.144 .098 & 23.081 .615 & 50.175 .219 & \\
\hline Laba Investasi & $2.68 \%$ & & & & & \\
\hline BEP & 4,1 tahun & & & & & \\
\hline
\end{tabular}

Break Even Point (BEP) sering disebut juga titik impas, yaitu titik biaya dan manfaat bertemu. Pertemuan titik tersebut menandakan keseimbangan antara biaya pengeluaran dan manfaat yang didapat. Berdasarkan tabel di atas, BEP akan terjadi pada tahun keempat.

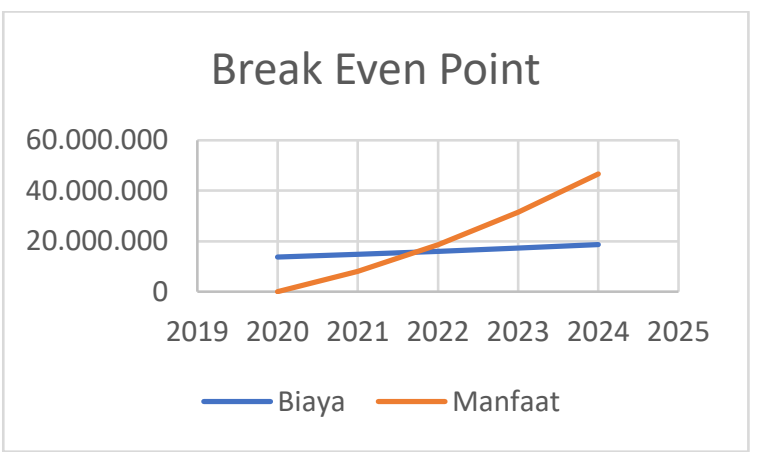

Gambar 1. Break Even Point

\subsection{Tahap Analisis}

\subsubsection{Kebutuhan Perancangan Sistem}

Untuk mengoperasikan sistem, maka dibutuhkan perangkat keras berupa komputer. Dalam perpustakaan sekolah dibutuhkan setidaknya 2 buah perangkat komputer untuk menunjang anggota dan petugas perpustakaan (Setyohadi \& Riskiawan, 2016). Selain perangkat keras, dibutuhkan juga perangkat lunak, yaitu:

1) Lisensi Windows 10

2) Microsoft SQL Server

\subsubsection{Fungsi}

Sistem informasi perpustakaan berbasis web berfungsi untuk memudahkan pengolahan data, mengurangi kesalahan pada input data, serta untuk mempermudah anggota dalam melakukan pencarian buku (Maryono \& Darwati, 2017). Dengan fungsi tersebut, petugas dan anggota diharapkan dapat memaksimalkan manfaat dari sistem informasi perpustakaan sekolah.

\subsubsection{Pengguna}

Sistem perpustakaan sekolah mempunyai 2 entitas pengguna, yaitu:

1) Admin

Petugas perpustakaan berperan sebagai admin. Tugas dari admin yaitu melakukan pengolahan data, melakukan transaksi pinjammeminjam buku dan membuat laporan.

2) User

Anggota perpustakaan berperan sebagai user. User bisa melakukan pengisian buku tamu dan melakukan pencarian buku.

\subsubsection{Diagram Use Case}

Diagram Use Case adalah diagram yang menggambarkan keadaan dari suatu sistem. Berikut gambar diagram use case untuk perpustakaan sekolah:

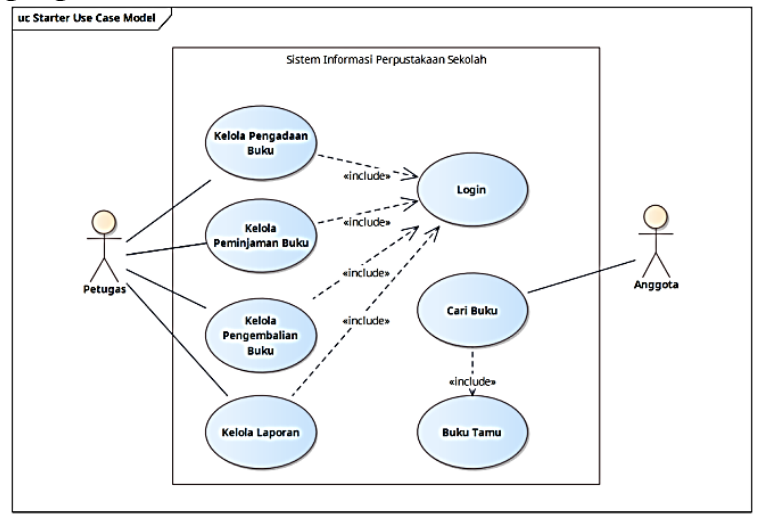

Gambar 2. Use Case Diagram

Setelah petugas login, petugas dapat melakukan pengolahan pengadaan buku, pinjammeminjam buku dan mengelola laporan. Jika anggota datang ke perpustakaan, anggota wajib mengisi buku tamu dibantu oleh petugas. 
Anggota bisa mencari buku yang ada diperpustakaan.

\section{Hasil dan pembahasan}

Tampilan pada web perpustakaan diutamakan untuk petugas perpustakaan yang digunakan untuk mengolah data pinjammeminjam buku. Sedangkan untuk anggota perpustakaan dapat melakukan pencarian buku dengan lebih mudah.

\subsection{Halaman Login}

Halaman Login hanya bisa diakses oleh petugas perpustakaan. Saat memasuki halaman web, petugas akan melakukan login menggunakan username dan password. Setelah melakukan login, petugas bisa melakukan pengolahan data perpustakaan sekolah.

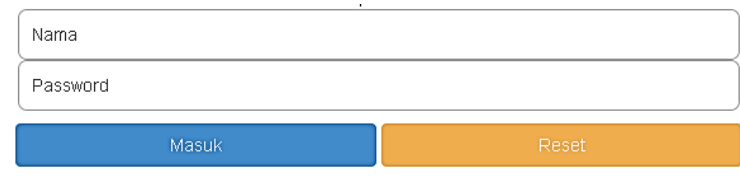

Gambar 3. Halaman Login

\subsection{Halaman Kelola Pengaadaan Buku}

Halaman ini dibuat agar petugas perpustakaaan bisa memasukkan data buku bacaan yang baru datang ke perpustakaan. Pada halaman ini, petugas dapat menambahkan nomor, tanggal, judul, pengarang, penerbit, tahun terbit, asal dan klasifikasi.

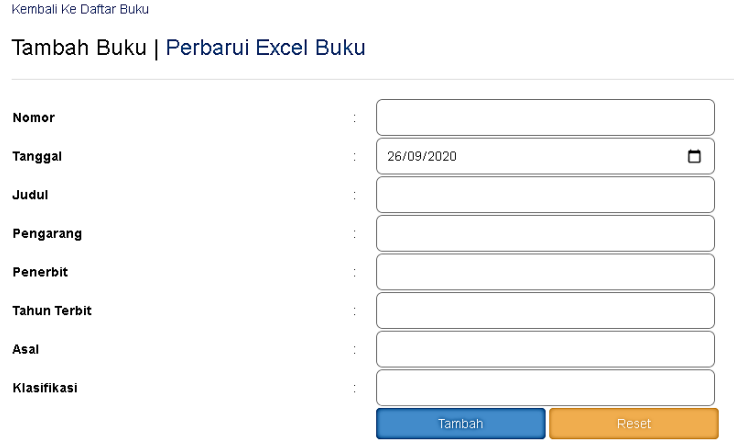

Gambar 4. Halaman Kelola Pengadaan Buku

\subsection{Halaman Peminjaman Buku}

Jika anggota melakukan peminjaman, petugas akan masuk ke halaman peminjaman buku. Lalu, petugas memasukkan data anggota yang meminjam. Data yang dimasukkan yaitu nomor buku, nama siswa, kelas dan tanggal pinjam.

Data Peminjaman Buku

Gambar 5 Halaman Peminjaman Buku

\subsection{Halaman Laporan}

Halaman laporan dapat membantu petugas saat melakukan laporan pinjam-meminjam buku di perpustakaan. Pada halaman ini, petugas dapat melihat laporan buku yang sedang dipinjam atau sudah dikembalikan. Petugas juga bisa melihat data peminjaman buku yang sebelumnya sudah dibuat. Pada data tersebut, bisa dilakukan perpanjangan masa peminjaman dan penghapusan jika buku sudah dikembalikan.

\section{Laporan}

$$
\text { Jumlah Buku : } 2
$$

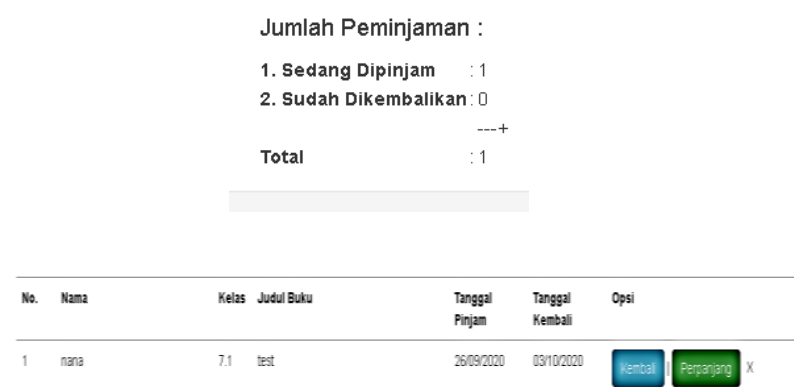

Gambar 6 Halaman Laporan

\subsection{Halaman Buku Tamu}

Halaman ini dibuat untuk anggota yang memasuki perpustakaan. Ketika memasuki perpustakaan, anggota akan dituntun oleh petugas perpustakaan menuju komputer khusus anggota. Setelah itu, anggota melakukan pengisian buku tamu. 


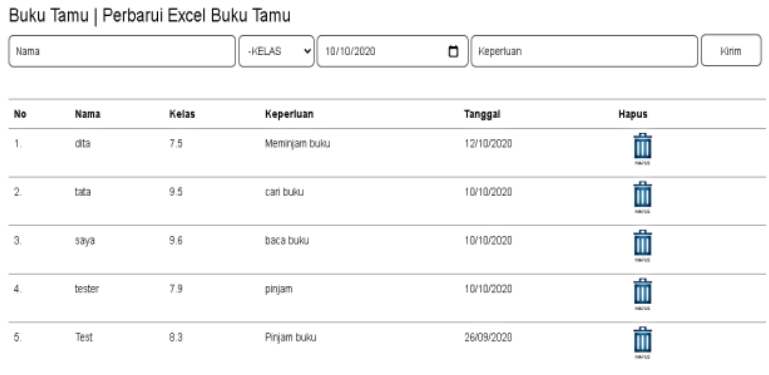

Gambar 7 Halaman Buku Tamu

\subsection{Halaman Pencarian Buku}

Setelah melakukan pengisian buku tamu, anggota dapat melakukan pencarian buku. Keterangan buku akan terlihat di halaman ini. Jika buku belum dipinjam akan tertulis "tersedia". Sebaliknya, jika buku sedang dipinjam akan tertulis "dipinjam".

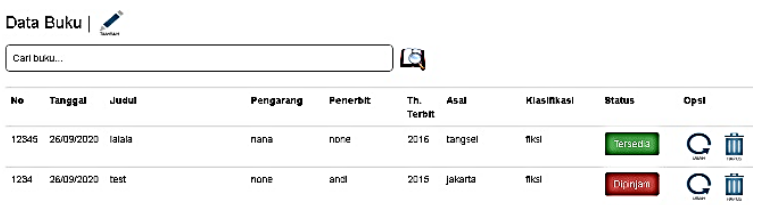

Gambar 8 Halaman Pencarian Buku

\section{Kesimpulan}

Berdasarkan penelitian yang telah dilakukan, dapat disimpulkan bahwa, mengganti sistem manual dalam pengolahan data dengan sistem informasi menggunakan web dapat meningkatkan efisiensi perpustakaan sekolah. Selain itu, pengembangan sistem memudahkan petugas perpustakaan dalam memproses data dari peminjaman dan pengembalian buku. Serta, memudahkan siswa/siswi serta guru untuk mencari informasi buku yang ada di perpustakaan.

\section{Saran}

Saran yang bisa kami berikan untuk peneliti selanjutnya agar bisa melakukan pengembangan yang lebih baik, mengingat akan banyak perkembangan di masa depan.

\section{Referencsi}

Adithama, S. P., \& Maslim, M. (2019). Pembangunan Sistem Informasi Perpustakaan. Jurnal Pengabdian Kepada Masyarakat, 3(2), 350360.

Aini, N., Wicaksono, S. A., \& Arwani, I. (2019). Pembangunan Sistem Informasi
Perpustakaan Berbasis Web. Jurnal Pengembangan Teknologi Informasi dan Ilmu Komputer, 3(9), 8647-8655.

Anggoro, D., \& Hidayat, A. (2020). Rancang Bangun Sistem Informasi Perpustakaan Sekolah Berbasis Web. Jurnal Pendidikan Informatika, 4(1), 151-160.

Hanum, W. S., \& Saifudin, A. (2019). Rancang Bangun Aplikasi Panduan Pariwisata di Kabupaten Banyuwangi Mobile Berbasis Android. Jurnal Teknologi Sistem Informasi dan Aplikasi, 2(2), 59-65. doi:10.32493/jtsi.v2i2.2798

Khudri, A., \& Oktariansyah, M. D. (2020). Sistem Informasi Perpustakaan Sekolah. Seminar Hasil Penelitian Vokasi (SEMHAVOK). Palembang: Universitas Bina Darma Palembang.

Maryono, Y., \& Darwati, I. (2017, September). Perancangan Web Perpustakaan Pada SMP Taruna Bhakti Depok. Jurnal Pilar Nusa Mandiri, 13(2), 240 -242.

Pratala, C. T., Asyer, E. M., Prayudi, I., \& Saifudin, A. (2020). Pengujian White Box pada Aplikasi Cash Flow Berbasis Android Menggunakan Teknik Basis Path. Jurnal Informatika Universitas Pamulang, 5(2), 111-119. doi:informatika.v5i2.4713

Pressman, R. S. (2015). Rekayasa Perangkat Lunak: Pendekatan Praktisi Buku I. Yogyakarta: Andi.

Puspitasari, D. (2016, September). Sistem Informasi Perpustakaan Sekolah Berbasis Web. Jurnal Pilar Nusa Mandiri, 12(2), 229-239.

Putera, A. R., \& Ibrahim, M. (2018). Rancang Bangun Sistem Informasi Peminjaman dan Pengembalian. Journal of Computer and Information Technology, 1(2), 57-61.

Setyohadi, D. P., \& Riskiawan, H. Y. (2016). Installasi Dan Konfigurasi Sistem Informasi Perpustakaan. Seminar Hasil Penelitian dan Pengabdian Masyarakat Dana BOPTN. Jember.

Shalahuddin, M., \& Sukamto, R. A. (2014). Rekayasa Perangkat Lunak: Terstruktur dan Berorientasi Objek. Bandung.

Yulistina, S. R., Nurmala, T., Supriawan, R. M., Juni, S. H., \& Saifudin, A. (2020). Penerapan Teknik Boundary Value Analysis untuk Pengujian Aplikasi Penjualan Menggunakan Metode Black Box Testing. Jurnal Informatika Universitas Pamulang, 5(2), 129-135. doi:10.32493/informatika.v5i2.5366 